\title{
SERVITIZATION OF PUBLIC SERVICE PROCESSES WITH A SIMULATION MODELLING APPROACH
}

\author{
LÁSZLó BUICS BOGLÁRKA EISINGERNÉ BALASSA
}

\begin{abstract}
A B S T R A C T
This article aims to examine how the theory of co-production can be connected with servitization and digitalisation and used together for the public service development with the help of discrete-event simulation modelling to highlight time-related deficiencies of a complex public service process, which is most commonly used by patchwork families. Data was taken from the Guardianship Office in Györ (Hungary), based on which in-depth interviews were conducted. Based on the legal background and the interviews, the authors of the article created the process model of the contacting procedure. Based on the model, discrete-event simulation was used to identify the process elements for potential improvement through servitization. Discrete-event simulation showed the insufficiency of national regulation regarding the whole process and weaknesses of the contacting procedures in terms of quality and success. Basic reasons were found for the dissatisfaction expressed by participants of the procedures (administrators and customers). The increasing customer demand for high quality and efficient public services and failures in the New Public Management (NPM) in Eastern European countries require other approaches to advance. The paper connects the theory of co-production and servitization in a public service context and demonstrates how a complex public service can be examined with this approach to find possible improvements. The government must change the process regulation considering the number of the cases, the workload of administrators and family types (divorced or patchwork). The emphasis should be placed on the training and experience of administrators.
\end{abstract}

KEY WORDS

co-production, digitalisation, discrete-event simulation, public service processes, servitization
László Buics

Széchenyi István University, Hungary ORCID 0000-0002-2810-4982

Corresponding author: e-mail: buics.laszlo@sze.hu

Boglárka Eisingerné Balassa

Széchenyi István University, Hungary ORCID 0000-0003-2894-5615

\section{INTRODUCTION}

In the age of ever-increasing stakeholder expectations, developing new and improving on existing public services is a challenge for every government (Lathrop et al., 2010; Ringold et al., 2013; O’Toole,
2015). These expectations in the globalised and rapidly digitalising world are pushing governments to find new ways to meet the needs of their citizens at the same or higher levels of efficiency than before (Casalino et al., 2013). Because of this, public

Buics, L., \& Eisingerné Balassa, B. (2020). Servitization of public service processes with a simulation modelling approach. Engineering Management in Production and Services, 12(3), 116-131. doi: 10.2478/emj-2020-0023 
administration as a profession is facing increasing stakeholder expectations (Lathrop et al., 2010; Ringold et al., 2013; O’Toole Jr. \& Kenneth, 2015). Solving complex problems of knowledge economy requires the collaboration of different actors for regions to mobilise and utilise sources, accelerate growth and improve competitiveness (Tamándl et al., 2014). The satisfaction with actors of the public sector can improve the competitiveness of cities (Filep et al., 2010). Citizens of a state can be considered as customers, but customer satisfaction is a complex concept, which is difficult to define properly (Stoker, 2006; Meynhardt, 2009). Moreover, the most attractive opportunities for IT companies are the solutions required by governments, manufacturing companies, and banks, so the IT companies are also interested in entering a new market (Reicher, 2014). In Eastern European countries, the dominant approach in the public service sector is the Weberian model (Jenei, 2009; Drechsler, 2009; Hajnal et al., 2018). After the change of the regime in the Eastern European countries, governments started to improve their public sectors. First, they used the New Public Management model to change the public services using available positive examples (Barberis, 1988; Kettl, 1995; O’Toole, 1997; Kaboolian, 1998; Terry, 1999; Lindquist \& Paquet, 2000; Stark, 2002; Hood \& Peters, 2004). The expectation for NPM was to improve the methods used and to make them more flexible to achieve higher consumer satisfaction in the public sector. Of course, there were also examples for making things worse than before (Osbore \& Gaebler, 1992; Mintzberg, 1996; Drechsler, 2005) as NPM proved to be ineffective in terms of several aspects at a later stage, especially in Eastern European countries (Pollitt-Bouckaert, 2000; Hajnal, 2004; Drechsler, 2005; 2008; Nemec, 2010; Bouckaert, 2011; Drechsler et al., 2015).

The purpose of this paper is to examine possible ways to apply the long-existing phenomenon of servitization (Vandermerwe \& Rada, 1988) in the field of public administration and use it for the development of a complex public service. While the concept of servitization is well-known in the manufacturing contexts, it has not or rarely has been used for public services.

Servitization generally means developing innovative capabilities that could complement and enhance product offerings. However, in this case, the authors of the article did not apply servitization to products but examined ways to improve the organisational capacity of a government agency to enhance the offered service. The paper connects the theory of co-production and servitization in a public service context and demonstrates how a complex public service can be examined using this approach to find possible improvements. The paper gives an overview of current research trends while examining how governments can use digital solutions for the servitization of public services.

The article uses the contacting procedure of Hungarian guardianship offices as an example. It discusses the steps of this complex service, demonstrates the specifics of the guardianship procedure and uses a simulation modelling approach to visualise and analyse the service process. Because this service is mostly used by patchwork families to settle issues, the nature of patchwork families - as the main customers of the service process and who would benefit the most from the servitization improvements - is discussed to help understand the nature and complexity of the service.

The main research question focuses on the possibility to improve elements of a complex service. This paper is the first phase of a lengthier research effort, trying to identify the possibilities and restrictions of the application of servitization-based solutions in the public field.

As a result of the research, the simulation highlights the time-related deficiencies of the service process as it shows how much longer it takes to finish the process in reality compared to how regulations define it, and how this situation affects the administrators who have to pay the penalty if the service delivery takes too long. Timely delivery is also essential for the head of the guardianship office, as it is the basis for effectiveness and judgement.

Time is a relevant factor in public service. Consumers find it important to receive the results of the public service as quickly as possible and of the highest quality possible. Services can be divided into different categories based on their complexity (Benedettini \& Neely, 2015). Some services are less time consuming and can be easily standardised and digitalised, e.g., applying for a passport or renewing an ID card. In many countries, these public services are available from home, so for customers who do not want to go to the office personally, everything can be arranged online. But there are also more complex public services which are much more time consuming and their digitalisation and optimisation could be exceedingly difficult.

Administrators of these public services play a crucial role in service provision. Customer satis- 
faction is greatly based on their skills as well as personality and attitude. The measure for the success of a service is customer satisfaction or dissatisfaction. The success of good governance of the respective offices is measured by the satisfaction of clients at the end of the administered case. Satisfaction is a complex issue. Nobody enjoys such administrative procedures; therefore, the services must be fast, sensitive and definitely successful. Clients prefer cases to be administered in one place or at least with little legwork. Different types of business conduct can be encountered in district offices. Some cases are referred to as typical and affect the majority of clients, while others affect only a small target group. One such small target group is patchwork families, which are a specific group affected in many cases. Patchwork families are complex, and the literature considers them to be inhomogeneous, providing several different types.

Patchwork families encounter several challenges in different areas of life. The arrangement and operation of reorganised families and the preservation of the mental health of their members are interesting areas for family psychologists. Sociologists, however, focus on the emergence of new family types and the resulting social changes and challenges. Marketing professionals perceive patchwork families as a potential target market, which also buys products and product portfolios that are different from those selected by traditional families, basing purchase decisions on different mechanisms. Due to a complex family model, workers living in patchwork families require more empathy, attention and more flexible working hours from corporate HR departments.

It is incredibly difficult to optimise these service processes and analyse their elements. As NPM cannot provide practical solutions for this problem, other methods and approaches must be found. An examination of the education system by Rámháp et al. (2017) led to a conclusion that public institutions should apply marketing and management techniques originating from the business to respond to challenges arising in the environment and adapt their competitive ability (Filep \& Kovács, 2005). The theory of Co-Production and Co-Creation (Boyle \& Harris, 2009; Durose et al., 2013; Nambisan, 2013; Osborne et al., 2013, 2016) provides a practical way to plan and deliver public services. Servitization offers a unique approach to the use of new methods for the analysis and development of public services.
The paper first presents the theoretical background of co-production and servitization. Next, it offers the background of the examined contacting procedure and the nature of patchwork families who are the most common customers of this service. Then, the background of discrete-event simulation is given and the details of the collected data, which were used to create the simulation of the service process. The remaining part of the article discusses the results of the simulation and benefits for customers and facilitators from the improvement of the service.

\section{LITERATURE REVIEW}

\subsection{Co-Production AND SERVITIZATION IN PUBLIC ADMINISTRATION}

In the last decades, as technology and society developed, governments realised the necessity to find new ways and methods to improve public services and maintain their efficiency as well as to answer to the changing needs of citizens to secure the satisfaction of the public. With growing expectations, old-school bureaucratic processes and the lack of fast and efficient solutions often turn people against the government, leaving a poor permanent impression (Richwine, 2012).

According to Nemec et al. (2019), while many research papers focus on co-production and cocreation in the international body of literature, only a few originate from Central and Eastern Europe. This paper aims to help fill this gap by focusing on intricate public services, such as the contacting procedure used at the Hungarian guardianship office. This research aims to emphasise the importance of the role played by public service employees in such processes as they are an essential part of the service just as customers.

According to Osborne et al. $(2013,2016)$, coproduction is one of the public policy reforms, which can be considered an effective way to plan and deliver public services (Boyle \& Harris, 2009; Durose et al., 2013; Nambisan \& Nambisan, 2013). Osborne et al. presented the conceptualisation of co-production and highlighted how it was theoretically rooted in both public management and service management theory (Osborne \& Strokosch, 2013).

In public administration and management literature, co-production originated from efforts by 
Ostrom (1972) and also by Alford (2014), who reevaluated Ostrom's work. The literature on the New Public Management presents co-production as "consumerism", and also, it can be found in the literature of the New Public Governance as well as a systems-level approach to public service delivery methods.

According to Osborne et al. (2016), the theory focuses on the way of adding service user participation to the whole service process aiming to increase quality. However, from the service management perspective, the literature says that co-production is already an essential and core component of service delivery and delivery is inseparable from co-production (Osborne et al., 2016). Users have no choice, which means that co-production happens whether they know it or not; thus, co-production is an intrinsic process of interaction between service providers and users when the service delivery happens (Osborne et al., 2016).

Osborne et al. (2016) focused on the relationship between co-production and the co-creation of value through public service delivery and explored this relationship further in a detailed literature review. It resulted in the definition of "co-production as the voluntary or involuntary involvement of public service users in any of the design, management, delivery and/or evaluation of public services" (Osborne et al., 2016, p. 2).

Nabatchi et al. (2016) also defined co-production as "the involvement of both users and public sector professionals in the delivery of public services"; however, they also highlighted that "this definition is neither used consistently nor applied in ways that make clear what does (and does not) constitute co-production" (Nabatchi et al., 2016).

Because of various other definitions and interpretations, Nabatchi et al. (2017) summarised the need to clarify whether services of a guardianship office in general and the contacting procedure in particular could be examined from the co-production point of view, especially because of the nature of this complex service. According to Alford (2014), in the case of co-production, public service providers can be considered regular producers and customers (citizens) - the co-producers of the service process. However, while some authors (Brudney \& England, 1983; Parks et al., 1981; Pestoff, 2006) stated that involuntary participation with one party feeling obligated to participate in the service process could not be considered as co-production, other authors (Alford, 2002, 2006, 2009; Osborne et al.,
2016) disagreed. In terms of this contradiction, the authors of this article agree with the latter and, thus, examined the contacting procedure from the point of view of co-production.

Servitization can be defined as the innovation of an organisation's capabilities and processes to better create mutual value through a shift from simple selling to an integrated product and service offering that delivers value in use (Vandermerwe \& Rada, 1988; Neely, 2008; Neely et al., 2011). There are similarities between private organisations and public service providers as they both aim to improve customer satisfaction, efficiency and effectiveness, but they also differ from each other in many ways.

Servitization now refers to the process of creating value by providing additional services to products (Vandermerwe \& Rada, 1988). Since its first appearance, the term was studied from several angles by scholars to uncover a different kind of methods and implications of service-led competitive strategies for manufacturers (Wise \& Baumgartner, 1999; Oliva \& Kallenberg, 2003; Slack, 2005; Shikata, 2019).

In the last three decades, servitization has been a popular strategy in the manufacturing sector, and according to the relevant literature regarding the manufacturing industry, an increasing number of companies are complementing their products with value-added services (Vandermerwe \& Rada, 1988; Wise \& Baumgartner, 1999; Fang et al., 2008; Baines \& Lightfoot, 2009; Kozłowska, 2020). Also, scholars have shown a steady interest in the understanding of how firms create value by adding services to products (Cusumano et al., 2015; Németh \& Döry, 2019).

Numerous examples of servitization include areas of finance, transportation, manufacturing (Dachs et al., 2012) and education (Arantes, 2020). According to the literature, servitization is usually a subscription model and can be applied to most industries in one way or another. It developed out of the necessity for businesses to remain profitable and competitive in an age where the financial aspects of design and manufacturing are becoming increasingly more challenged by emerging markets and, apparently, the concept of servitization is in strong connection with value delivery.

The servitization of public services seems to be a noble but also a tricky challenge. Several significant differences exist between private and public service providers, including, e.g., the lack of competitors. However, in essence, the ultimate goal of governments and private companies are basically 
the same. Although the approach may be different (top-down, bottom-up), they both aim to satisfy customers and save money while increasing efficiency and effectiveness and (Kurucz, 2016). Despite other reasons, public satisfaction is important for the government as much as for companies. However, to satisfy customers by adapting and creating new and even better products and services, it is important to know what they think about the existing situation.

According to Hockerts and Waver (2002), three main forms of Product-Service Systems exist. The first is product-oriented, and in this case, the customer gets the ownership of the product while the manufacturer provides additional services, which are related to the product directly. The second is use-oriented, where the service provider retains the ownership of the product and uses a modified distribution and payment system, such as sharing or pooling to sell the functions of the product. The third is result-oriented, in which case the provider replaces services for products (Hockerts \& Weaver, 2002).

Neely $(2009,2012)$ extended this list with two additional categories to be able to include the full scale of servitization applications and results (Neely, 2009, 2012).

The two new categories are integration-oriented Product-Service Systems and service-oriented Product-Service Systems. In the first case, companies conduct a vertical integration adding services at the downstream of their value chain. In the second case, companies provide new services for their products in a way that they integrate those services into products (Neely, 2009, 2012).

According to Neely $(2012,2013)$, there are four main categories of reasons behind the application of this phenomenon: economic, strategic, environmental and technological (Neely, 2012, 2013). The first three main categories are usually considered more or less responsible for applying the concept of servitization by companies, but there is one more category, which increasingly accelerates the shift and can be considered as a major driver of servitization. This category is technological reasons (Neely, 2012, 2013).

At one point, technology was only considered as an enabler of servitization approaches. However, with the tremendous amount of new innovations introduced in the last three decades, the world is now one big pool of infinite data which can be collected and analysed in many ways to gain valuable information about customer demands and trends. Thus, the potential for new and innovative services grows with every year. According to Lightfoot and other researchers, technology will enable a higher level of service delivery, and future products and services can be tailored to individual product needs of customers. This is possible thanks to the upcoming age of The Internet of Things (IoT), which will greatly accelerate the servitization in the future as it will turn the physical world into a digital information centre (Baines \& Lightfoot, 2013).

"The technology - and particularly the ability to capture and analyse "big data" - open up some new opportunities for service innovation" (Neely, 2013, p. 3).

While governments are trying to meet the growing expectations of citizens, the relationships between a citizen and a public institution become more and more complex as they mutually influence each other. Numerous IT tools are available to be transferred to the public sector to increase customer satisfaction, efficiency and effectiveness (Süle, 2018).

Manufacturing companies choose servitization due to economic, strategic, environmental and technological reasons. The same reasons apply to the public sector as well. Digitalisation and new technological solutions are already present in most public administration systems on different levels as the world approaches the age of e-government and e-governance (Jeong, 2007). While private companies and public organisations are different in many terms, fundamentally they both aim to create more effective and efficient solutions, which are not just economically acceptable but also satisfy customer needs. In other words, governments started attempting the servitization of public services. The literature clearly shows that servitization is much more than simply the creation of additional services. It also changes the way how products and services are perceived.

\subsection{THEORETICAL BACKGROUND OF PATCH- WORK FAMILIES}

Professionals representing different disciplines have been dealing with the sociological and psychological analysis of the lifestyle of stepfamilies (Cheal, 2002). The actuality of the topic is proved by the rise in the number of stepfamilies, which has become a worldwide phenomenon. While 83 per cent of children in stepparent families live with their natural mother, there appears to be little recognition of the 
difference between "intact" and "blended" families (Beck \& Gernsheim, 2002). In the Christchurch Health and Development Study, nearly one in five children had experienced three or more family situations by the age of nine (Fergusson et al., 1984). In the United States, 12-year olds who had experienced more than two family changes were more likely to show disruptive behaviour in school than those who had experienced none (Kurdek et al., 1995).

The United States Census Bureau (2003) reported that 16 per cent of all families with children living at home were classified as stepfamilies. In Hungary, every sixth child lives in a stepfamily (Spéder, 2005). Besides the rising international publicity (Ahuja et al., 1998; Felker et al., 2002; Beck \& Gernsheim, 2002; Fisher et al., 2003) several research programmes were started in this topic (Corfman \& Ehmann, 1987; Foxman et al., 1989; Schumaker Dyke, 2005).

Before introducing the literature background, it is inevitable to define what stepfamily means. (1) A stepfamily, also known as a blended family or reconstituted family, is a family, in which one or both members of the couple have children from a previous relationship. The member of the couple to whom the child is not biologically related is the stepparent, specifically the stepmother or stepfather (Mintel, 2005). (2) A blended family is a family that is formed when separate families are united by marriage or other circumstance (Barker, 2003, p. 46). (3) A reconstituted family (also known as a blended family) is the sociological term for the joining of two adults via marriage, cohabitation or civil partnership, who have children from previous relationships. (4) A new family made from the remnants of divorced families (Biblarz \& Gottainer, 2000).

In Germany, stepfamilies were first mentioned in 1984 (Sager et al., 1983). Earlier, such families were founded by the remarriage of widows with children. However, a large-scale rise in the number of divorces became the reason for the frequent creation of stepfamilies (Clarke \& Joshi, 2005). According to Sager (1983), a stepfamily is formed by marriage (or cohabitation) of two partners, of whom at least one had already been married. Visher and Visher (1995) defined a stepfamily as a symbiosis where at least one adult had the role of a stepparent. From the point of view of the systems approach, a nuclear family contains a couple or a parent subsystem and a child-sibling subsystem. Parents who do not live together with the family after the divorce play an important role in the life of the new family as well (Allan \& Crow, 2001). The importance of the role and values of the family was also emphasised by Huszka and Platz (2017).

McGoldrick and Gerson (1987) completed a family map with a genogram. From the outside, a stepfamily might not differ from a nuclear family; however, there is a significant difference between the two (Hetherington, 1999).

The analysis of stepfamilies reveals special importance of borders, positions, hierarchy and the connecting subsystems. The most important comprehensive typology was made by Sager (1983), who made a distinction between 24 types of stepfamilies. Papernow (1980) denoted two types, namely, (a) a simple stepfamily-system (one parent-child system and a stepparent) and (b) a complex family (the subsystem of two parents and a child). According to the opinion of Burgoyne and Clark (1981), more differentiated categories are necessary, and stepfamilies with one or more common child require a diverse definition.

Verena Krähenbühl (2011) et al. elaborated on a typology which distinguishes whether a stepfather or a stepmother joined the system: (1) a family with a stepmother, (2) a family with a stepfather, (3) a complex stepfamily, (4) a stepfamily with a common child or children, and (5) a part-time stepfamily. Stepfamilies are less solidary than other families, and they encounter conflicts due to differences of family members (Bien et al., 2002; Clingempeel et al., 2004; Tinson \& Nancarraow, 2007). Children have less voice in each decision since the family members do not want the situation to be more complex (Tinson et al., 2008). Their common thinking is family-centred, which is why it is often observed that they try to frame their lifestyle into that of normal families, denying the differences (Bray \& Berger, 1993). For the members of stepfamilies, one source of difficulties is that it is not clear what role is required from them (Fischer, 2005). These families have no common history; therefore, conflicts can occur regarding childupbringing and decision-making in connection with everyday tasks (Lawton \& Sanders, 1994). Research indicates that problems, such as poverty, mental health and behavioural issues, difficulties at school, and general health problems occur more often among the children (Cockett \& Tripp, 1994). The hardest problem to solve is the material clash. Money is extremely important in our lives. Although it is common for a household to manage finances together, some decision can be made separately 
(having separate bank accounts) (Lansford et al., 2001). Stepfamilies have to plan more than nuclear families, which can make household planning and marriage greatly important (Clark, 2008). However, the family type affects their purchase decisionsmaking and the characteristics of the process itself as well (Rogers-Rose, 2002; Brown, 2004). Eisingerné et al. examined the purchase decision process in patchwork families, stating a difference in the processes applied by patchwork families compared to nuclear families (Eisingerné et al., 2012; Eisingerné, 2014).

\subsection{UNWRAPPING THE CONTACTING PROCE- DURE}

The question may arise whether public services, district offices or their sub-departments have anything to do with patchwork families and their members. The answer is yes, and primarily at guardianship offices. The workers of guardianship offices deal with such cases daily, providing services to members of patchwork families. Typical cases for patchwork families are:

- cases related to alimony,

- contacting,

- open adoption matters.

Based on the literature review, it seems important to highlight the legal regulation applicable to contacting. According to the governmental decree 331/2006 (XII.23) on the roles and responsibilities in child protection and guardianship affairs and on the authority and jurisdiction of guardianship offices, par. 9, the district office for child protection and guardianship affairs (guardianship office):

- decides about the communications between the child and the parent, or another person in charge of contacting, orders monitored contacting in justified cases, and also orders the mandatory child protection mediation procedure or the use of the mandatory supported procedure,

- disposes of the enforcement of the court's or the guardianship office's regulation on communications.

The following laws apply to the activities of the guardianship office in general and contacting procedure in particular:

- Pars. 4:178-185 of Chapter 18 on exercising parental supervision of the Fourth Book (Family Law) of Act V of 2013 on the Civil Code deal with communications.

- Article 4 (pars. 27-33/B) of 149/1997 (IX. 10.) Government Decree on the guardianship offices and the proceedings of child protection and guardianship cases deals with contacting.

- Act CL of 2016 on general administrative order, which entered into force on 1 January 2018, disposes of the rights and obligations of the clients, of the general administrative deadline and of the rules of conducting the administrative procedure. Act XXXI of 1997 on child protection and guardianship administration, disposes of the rights and obligations of the child and the parent, and on the main rules of child protection and guardianship administration.

- The above acts were considered as "literature" as well as Chapter XVI of the 2nd volume of Polgári jog kommentár (commentary on civil law commentary) edited by Dr Ferenc Petrik.

- The national government office judges the requests for legal remedy handed in against the decisions of the official procedure of the first instance; the office also states its own professional case regarding unique decisions, and according to a determined plan, executes the control of the authority of the first instance and the target examination of each field, and in doing so, it has supervision over the authorities of the first instance.

The basics of the research are provided in the model below, which is the basic model of the contacting procedure applied by guardianship offices (Fig. 1). This model illustrates the above-mentioned procedure, for the administration of which the law ensures 60 days. The procedure is considered a "production process". The pending question for the continuation of the research is whether this model is applicable in the case of patchwork families in its current form and whether 60 days were enough for the procedure involving patchwork families as participants.

\subsection{Discrete-eVent Simulation}

A simulation is an imitated operation of a real process or system over time. This includes the creation of an artificial history of the system and the observation of this artificial history in order for the creator to draw conclusions about the operational characteristics of the real depicted system (Bernard et al., 2000; Bohács, 2012).

A discrete-event simulation model is defined as one, in which the state variables change only at those discrete points in time, at which events occur. Discrete-event system simulation is the modelling of 


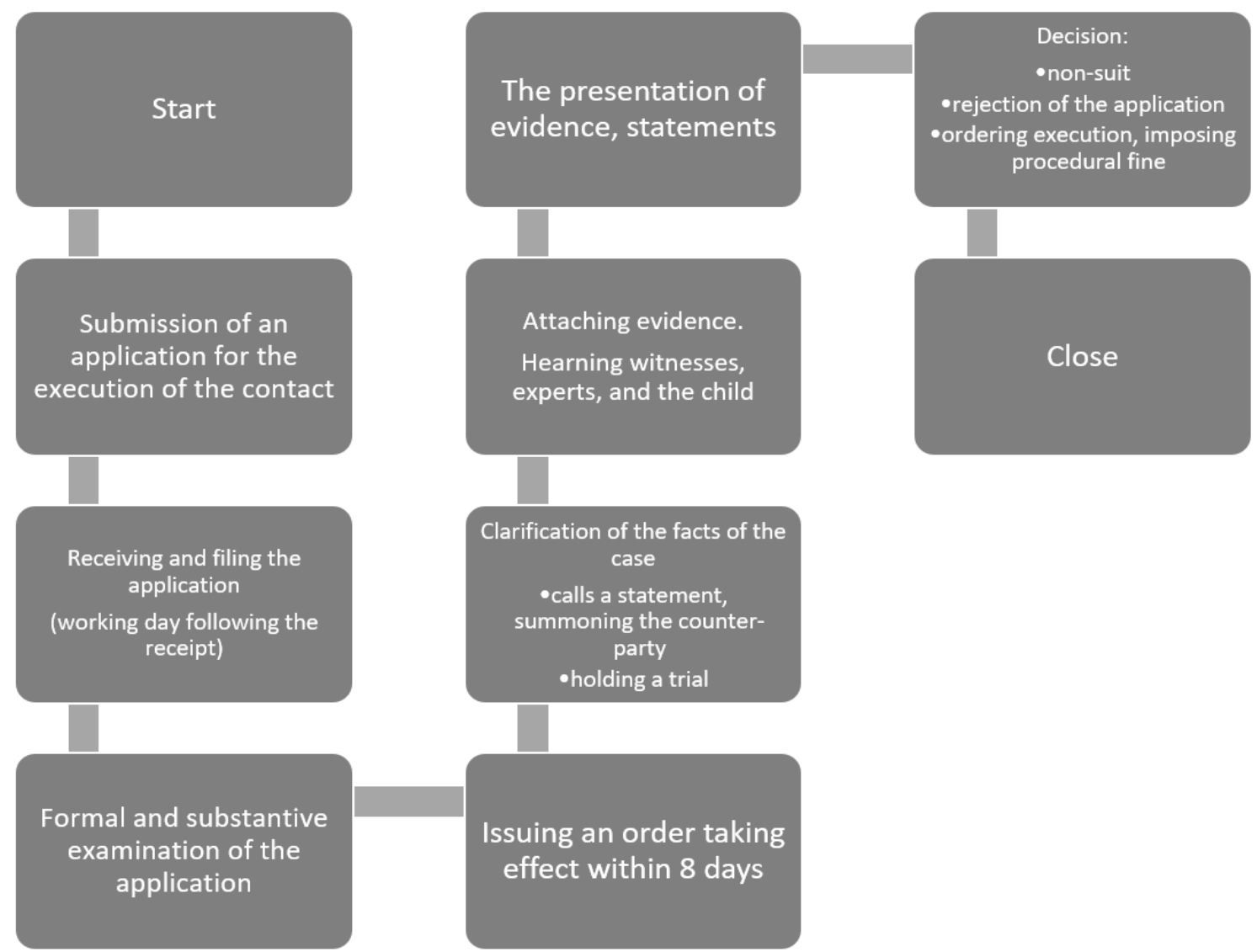

Fig. 1. Process steps of the contacting procedure

systems, in which the state variable changes only at a discrete set of points in time.

The discrete-event simulation tracks the state changes in the model components at the time the changes occur. Unlike continuous simulation, where the clock runs in a continuous manner, the clock in discrete-event simulation jumps from one scheduled event to the next. Events can schedule other events, such as an object entering a machine, which schedules an event for the same object to leave the machine. Discrete-event simulation only shows the state changes of the model components at certain points in time, not continually over time. When certain events take place, certain model components change their state and, thus, control the simulation (Bernard et al., 2000; Bohács, 2012).

A simulation is a test, in which a system or the expected or actual behaviour of the system is studied in a physical or computer model of the process. Accordingly, simulations are simplifications of reality that focus more on the system as a whole and less on its details. The simulation imitates a real phenomenon with the help of the available alternative technological solutions, which most often means a simulation software developed for this purpose. The purpose of the simulation is to create the same or very similar conditions for users in the virtual environment at the model level as the simulated phenomenon. This allows using a virtual environment that mimics the operation of the original system to accomplish a specific task, which greatly facilitates, e.g., various efficiency and optimisation efforts (Bernard et al., 2000; Garrido, 2009).

The purpose of the simulation is to understand the features and essence of processes. It allows answering the question "What would happen if...?" without any financial or safety risks. Changes can be made to parameters, and different setups can be tried to find the optimal solution during the design or review phase. The simulation requires a model that properly describes the steps, relationships and features of the process. The level of detail and what "properly" means is always a valid question. These models are simplified descriptions of reality and, as a rule of thumb, the model should be simple but also detailed enough to grasp the general and studied behaviours of the real process (Bohács, 2012; Banks et al., 2013; Prateek, 2015; Martijn, 2017). 
The model not only describes the relationships and the steps of the processes but features of the steps. These features involve parameters such as processing times, input rate, etc. In the case of modelling an existing real-world process, such parameters must be measured or estimated as distributions to simulate significantly more cases than measured. The way the model is described is based on the framework that is used. Usually, simulation frameworks provide ways and tools to describe the models, while also allowing to "operate" or "run" these models. This framework, the set of rules that describe how to operate the model, can be executed manually or, more optimally, by software (Prateek, 2015; Martijn, 2017).

\section{RESEARCH METHODS}

This paper aims to examine how the phenomenon of servitization could be applied in the field of public administration and how it could be used for complex public service development. Servitization generally means developing innovative capabilities that could complement and enhance product offerings. In this research, the approach of servitization is applied in a public service context, and a complex contacting process is used as an example.

Data was collected from the Guardianship Office in Györ (Hungary), and in-depth interviews were conducted. Based on the legal background and in-depth interviews, the process model was created for the contacting procedure. Based on the model, discrete-event simulation was applied to identify the process elements where protentional improvements could be made through servitization.

The new model was used to create a simulation about the procedure, to examine the connection and relationship between the Governmental Regulation and the practice. Discrete-event simulation showed the insufficiency of the Governmental Decree regarding the whole process, weaknesses of the contacting procedures in the field of quality and success. The basic reasons for the dissatisfaction of the procedure participants (administrators, customers) were found.

In the discrete-event simulation, a specific case of a patchwork family) was used. Based on the theory of the authors, it was impossible for the administrators to conduct the whole procedure on time and with appropriate quality as, if required, it may involve doctors, policemen, teachers, kindergarten teachers, psychologist etc.
In the current phase of the research, the authors conducted seven in-depth expert interviews with the head and other employees of the Guardianship Office of Györ. The analysis of the model showed that the time factor, which is especially important for the procedure, was not indicated at all. Furthermore, the procedural elements, which may repeat or induce a further delay in the procedure, were not indicated either. For example, there is no indication that different parties have to be summoned during the procedure, which may take a long time due to the complexity of posting and notification. It may increase the duration of the procedure by two weeks.

The hearing of the experts (doctor, psychologist, teacher, and kindergarten-teacher) also takes a long time and slows the entire procedure down, making the close on time impossible. During the procedure, it would often be necessary to use a mediator. Each affected party can ask for a mediator, but the administrator can also offer the service. However, administrators often do not use this option as they are sure that the procedure would not be closed within 60 days in such a case.

Administrators have two choices. First, they can comply with the rules and decide on the time, in which case, the quality would be compromised. Such an option does not seem appropriate when dealing with people. Hence the second choice to exceed the time frame and concentrate on the quality. However, in this case, administrators fail to operate within the time limit (especially in the case of patchwork families), having to pay a fine of HUF 10.000 (EUR 30). None of the choices is good. In this situation, neither the administrator nor the affected parties would be satisfied.

Table 1 illustrates the complexity of the contacting procedure used at the Guardianship Office of Győr-Moson-Sopron County in 2017. Each case is divided into sub-numbers, which means that newer actions were submitted by parties during the procedures. Obviously, the higher are the sub-numbers, the more complex is the case, and the more the case bothers the participants. Furthermore, it increases the duration as well as the complexity of the procedure. It is a vicious circle, which is difficult to break.

Table 2 shows cases with sub-numbers, in which patchwork families are/were the participants. Sorted in the descending order, the data clearly shows that cases of patchwork families were more difficult. They had more files, used the more of the administrator's time and had little chance to be closed on time. 
Tab. 1. Contacting procedure of the Guardianship Office of Győr-Moson-Sopron County in 2017

\begin{tabular}{|r|r|r|r|r|r|}
\hline MAIN NUMBER & $\begin{array}{c}\text { SUB-NUMBER } \\
\mathbf{1 - 1 0}\end{array}$ & $\begin{array}{c}\text { SUB-NUMBER } \\
\mathbf{1 1 - 3 0}\end{array}$ & $\begin{array}{c}\text { SUB-NUMBER } \\
\mathbf{3 1 - 5 0}\end{array}$ & $\begin{array}{c}\text { SUB-NUMBER } \\
\mathbf{5 1 - 1 0 0}\end{array}$ & $\begin{array}{c}\text { SUB-NUMBER } \\
\text { ABOVE 100 }\end{array}$ \\
\hline 153 & 112 & 27 & 8 & & 4 \\
\hline
\end{tabular}

Tab. 2. Contacting procedure with patchwork families used at the Guardianship Office of Győr-Moson-Sopron County in 2017

\begin{tabular}{|c|c|}
\hline SUB-NUMBER & PATCHWORK FAMILIES \\
\hline 133 & M7 \\
\hline 112 & M13 \\
\hline 109 & M1 \\
\hline 95 & M5 \\
\hline 81 & $\mathrm{M} 2$ \\
\hline 58 & M6 \\
\hline 48 & M4 \\
\hline 37 & M8 \\
\hline 28 & M3 \\
\hline 14 & M9 \\
\hline 11 & M11 \\
\hline 10 & M12 \\
\hline 6 & M14 \\
\hline 6 & M16 \\
\hline 5 & M15 \\
\hline 2 & M10 \\
\hline
\end{tabular}

\section{RESEARCH RESULTS}

The research used the Tecnomatix Plant Simulation software by Siemens, which offers a wide range of tools to build and operate process simulations and imitate the behaviour of the real process. First, the process was built based on how it should look like according to the laws and regulations detailed before. The collected data was used to define the processing time parameters of each step (Fig. 2).

In the simulation, the objects moving from the source to the sink are individual cases. Each station of the simulation represents a main step of the contacting procedure, such as the examination on an application, attaching evidence, decision-making, etc. Five categories of moving objects were defined according to the data (Fig. 3).

By using methods to create simple programmes, the simulation becomes highly customisable, which is an excellent benefit of this simulation software as many different and complex scenarios can be probable.
After the simulation of multiple cases with the built model, the authors of the article concluded that the average time needed to finish a case was 49 days, which is within the frame of 60 days. According to this simulation, an ordinary case can be closed before the deadline, which is regulated by the law (Fig. 4). However, as previously discussed, some could take significantly longer to finish, and this was suggested by the information collected during the in-depth interviews. For example, according to the experience of the administrators, the complexity of posting and notification could increase the duration of the procedure by several weeks. However, these steps were not detailed in the original service process. Therefore, the posting and notification process was added to the simulation model, and its parameters were defined according to the experience of the administrators.

After rerunning the simulation, it turned out that the average time needed to finish a case was 81 days, which exceeds the current regulation by 21 days. The simulation results correspond to the experience of administrators who stated that sometimes, cases could run for several months and even longer due to their nature and complexity. One solution could be to improve the posting and notification process. It could be digitalised at least partially, as currently, this part of the process is completely manual and uses regular post and delivery methods as discussed before. Administrators dealing with a more complex case, in which multiple external actors should/could be involved, must notify them using regular post. Usually, replies are also received in the same way, whether the actors are sending back requested data, asking for more detailed information or just confirming that they are ready to participate.

While this difference reveals only one aspect of the complexity of a public service process, this research is the first to provide real proof in relation to for the contacting procedure and its failure to meet regulations. Thus, steps should be made to reevaluate the process regulation in detail and find ways to improve its efficiency and effectiveness. 


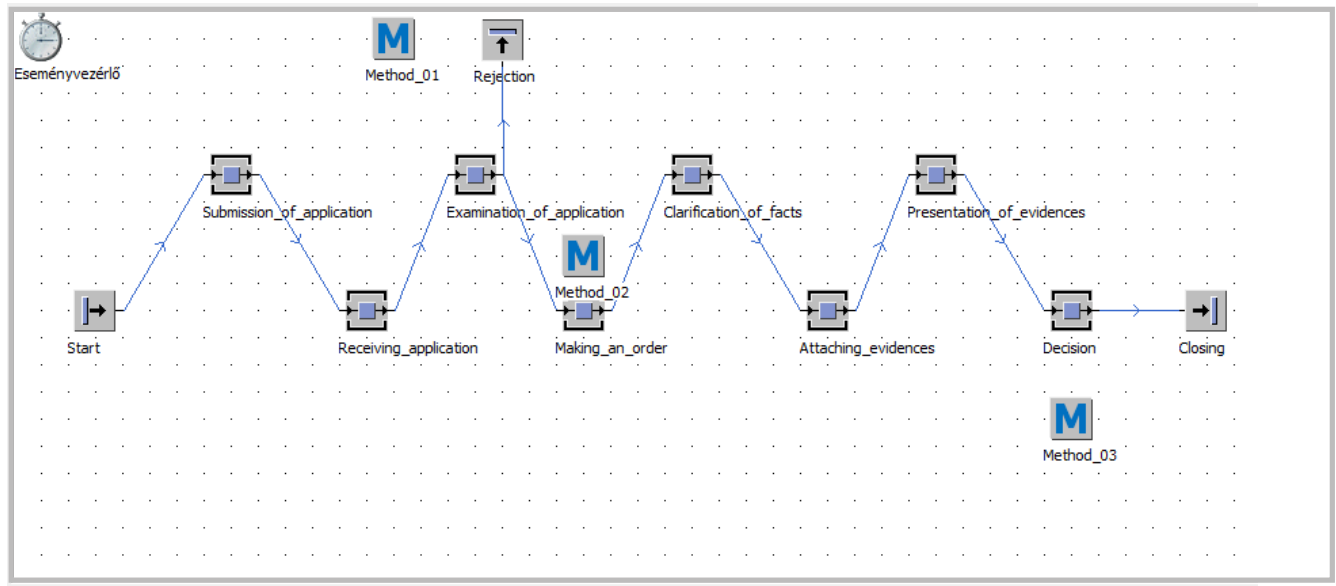

Fig. 2. Simulation model of the contacting procedure according to regulations

\begin{tabular}{|c|l|l|}
\hline & $\begin{array}{l}\text { object } \\
1\end{array}$ & $\begin{array}{l}\text { integer } \\
2\end{array}$ \\
\hline string & MU & Case number \\
\hline 1 & .MU.A & 112 \\
\hline 2 & .MU.B & 27 \\
\hline 3 & .MU.C & 8 \\
\hline 4 & .MU.D & 4 \\
\hline 5 & .MU.E & 2 \\
\hline
\end{tabular}

Fig. 3. Case categories and numbers defined

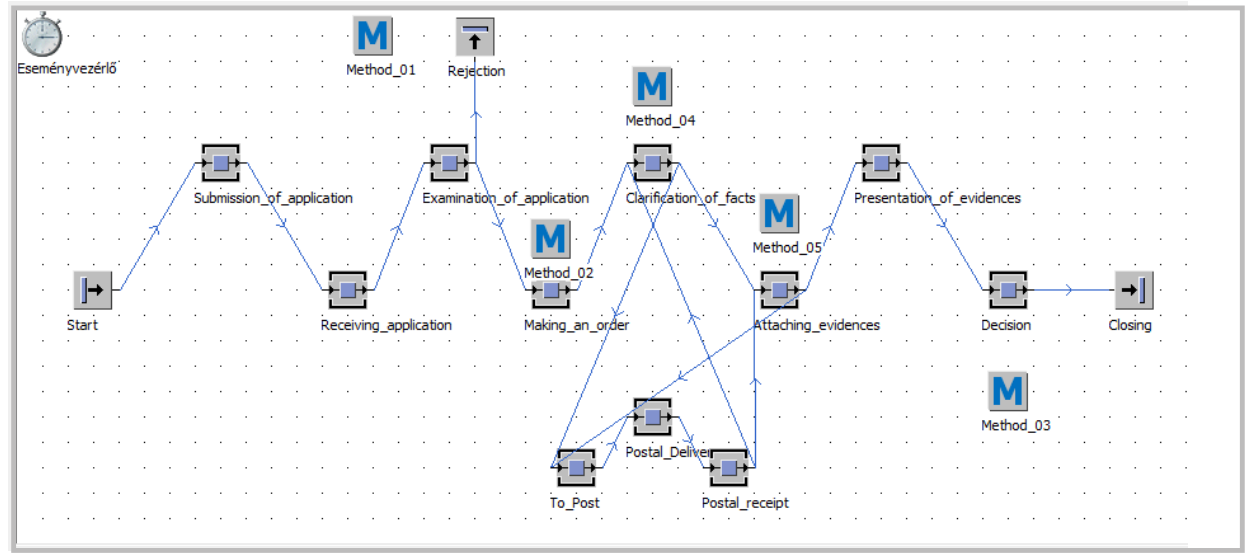

Fig. 4. Simulation model of the contacting procedure with the detailed posting process

\section{DISCUSSION OF THE RESULTS}

While digitalisation is not the only way towards the servitization of government services, the technological developments can make a significant impact (Sabbagh et al., 2012) on service operations and processes, which makes digitalisation a promising avenue to pursue. Trends in the private sector can provide good examples of innovation in terms of servitization approaches, which use digitalisation methods to increase efficiency and effectiveness (Dinges et al., 2015), and these innovative ideas could be useful in the public sector as well.

Researchers who studied servitization in the private sector or in the field of education generally agree that the technological advancements can lead to new servitization solutions because customers create increasingly more data, which can be analysed and used not just as feedback but also as a resource to predict future needs. In the very same way, governments could use the feedback of the administra- 
tors to create better services and to predict future needs, which could lead, e.g., to shorter queues and faster service.

In the last decades, as our technology and society rapidly developed, governments realised the necessity to develop new ways and methods for services to maintain efficiency and answer the changing needs of citizens to secure the satisfaction of the public.

The authors of this article believe that public service digitalisation and emerging e-government solutions can play the role of enablers and accelerators of the servitization of public service systems just as they earlier did in the private sector. However, because of the general differences between private and public service providers, new solutions should be implemented carefully.

We could see that contacting procedures are especially complex and lengthy. The law requires the administrators of the guardian office to strictly remain within the timeframe allotted for case administration; however, it does not consider either the complexity of the cases or different family types.

\section{CONCLUSIONS}

Based on the simulation model, the service process takes longer to finish than the allowed timeframe, which corresponds with the collected data and experience of the guardianship office administrators. The analysis of the model showed that the time factor of the procedure was not indicated at all. Furthermore, the procedural elements that may have to be repeated or create further delays in the procedure were not indicated either. For example, different parties have to be summoned during the procedure, which may take a long time due to the complexity of posting and notification. It may increase the duration of the procedure by up to two weeks.

This situation can immensely affect the quality, efficiency and effectiveness of these processes as administrators are forced to take shortcuts in some cases to save time, which also affects customer satisfaction. The research is the first effort that provided real proof for the contacting procedure and its failure to comply with regulations. Thus, steps should be made to re-evaluate the process regulation in detail and find ways to improve efficiency and effectiveness.
By using the theory of co-creation to examine a public service process and its steps and participants and combining it with a digital servitization approach, public services can be viewed from a new angle. In the case of complex public services, where administrators are an inseparable part of the process, their feedback and experience can be used to map and analyse the process and find possible improvements with the help of digital solutions.

This study presents the initial steps of the research. The further aim of the research is to describe the contacting procedure with the help of a model that includes all elements of the procedure and considers the time factor as well as the possible risks. After the creation of the model, the authors aim to introduce the actual time needed for the procedure with the help of simulation and to discuss the optimal timeframe of the procedure in the case of patchwork families. The long-term goal is to call the attention of decision-makers to optimise the procedural deadline to ensure the satisfaction of both parties and the administrators.

\section{LITERATURE}

Act CL of 2016 on the General Administrative Order Law.

Act V of 2013 on the Civil Code Fourth Book (Family Law) Chapter XVIII of the Exercise of Parental Supervision, Section 4:178. - 4:185.

Act XXXI of 1997 on the Protection of Children and Guardianship Administration (Child Protection Act) provides for children and parental rights and duties, as well as the main rules of child protection and guardianship administration.

Ahuja, R. D., Capella, L. M., \& Taylor, R. D. (1998). Child influences, attitudinal and behavioral comparisons between single parent and dual parent households in grocery shopping decisions. Journal of Marketing Theory and Practice, 6(1), 48-62.

Alford, J. (2002). Defining the client in the public sector: A social-exchange perspective. Public Administration Review, 62(3), 337-346.

Alford, J. (2009). Engaging public sector clients: From service-delivery to co-production. Springer.

Alford, J. (2016). Co-Production, Interdependence and Publicness: Extending public service-dominant logic. Public Management Review, 18(5), 673-691.

Alford, J., \& Speed, R. (2006). Client focus in regulatory agencies: Oxymoron or opportunity? Public Management Review, 8(2), 313-331.

Allan, G., \& Crow, G. (2001). Families, households and society. Palgrave.

Arantes, J. A. (2020). The servitization of Australian K-12 educational settings. Postdigital Science and Education, 1-29. doi: 10.1007/s42438-019-00097-0 
Baines, T., \& Lightfoot H., (2013). Made to Serve: How manufacturers can compete through servitization and product service systems, John Wiley \& Sons.

Baines, T., Lightfoot, H., Peppard, J., Johnson, M., Tiwari, A., Shehab, E., \& Swink, M. (2009). Towards an operations strategy for product centric servitization. International Journal of Operations \& Production Management, 29(5), 494-519.

Banks, J., Carson, J. S., Nelson, B. L., \& Nicol, D. M. (2013). Discrete-event system simulation: Pearson new international edition. Pearson Higher Ed.

Barberis, P. (1998). The new public management and a new accountability. Public Administration, 76(3), 451-470.

Barker, R. L. (2003). The social work dictionary (5th ed.). Washington, DC: NASW Press.

Beck-Gernsheim, E., \& Camiller, P. (2002). Reinventing the family: In search of new lifestyles. Cambridge: Polity Press.

Benedettini, O., \& Neely, A. (2012, June). Complexity in services: an interpretative framework. 23rd Annual Conference of the Production and Operations Management Society (POMS), 1-11.

Benedettini, O., \& Neely, A. (2013). Factors Influencing Service Complexity: The Perspective of Servitized Manufacturers. Cambridge Service Alliance Executive Briefing Paper. Cambridge, UK: University of Cambridge.

Biblarz, T. J. \& Gottainer, G. (2000). Family structure and children's success: a comparison of widowed and divorced single-mother families, Journal of Marriage and Family, 62, 533-548.

Bien, W., Hartl, A., \& Teubner, M. (2002). Stieffamilien in Deutschland. Eltern und Kinder zwischen Normalität und Konflikt. Opladen. Leske und Budrich.

Bohács, G. (2012). Folyamatelemzés és szimuláció. Jármüipari Felsőoktatási és Kutatási Együttmüködés, Európai Unió, Európai Szociális Alap.

Bouckaert, G., Nakrošis, V., \& Nemec, J. (2011). Public Administration and Management Reforms in CEE. Main Trajectories and Results. NISPAcee Journal of Public Administration and Policy, 4, 9-29. doi: 10.2478/v10110-011-0001-9.

Bray, J. H., \& Berger, S. H. (1993). Developmental Issues in StepFamilies Research Project: Family relationships and parent-child interactions. Journal of Family Psychology, 7(1), 76-90.

Brown, S. L. (2004). Family structure and child well-being: The significance of parental cohabitation. Journal of Marriage and Family, 66(2), 351-367.

Brudney, J. L., \& England, R. E. (1983). Toward a definition of the coproduction concept. Public Administration Review, 59-65. doi: 10.2307/975300

Casalino, N., Draoli, M., \& Martino, M. (2013, May). Organizing and Promoting Value Services in Public Sector by a New E-government Approach. Proceedings of XIV Workshop dei Docenti e Ricercatori di Organizzazione Aziendale (WOA 2013), Università La Sapienza, Rome.

Cheal, D. (2002). Sociology of Family Life. Palgrawve, MacMillan, Basingstoke.

Clarke, L., \& Joshi, H. (2003). Children's changing families and family resources. In Jensen A.-M., \& L. McKee
(Eds.), Children and the Changing Family: Between Transformation and Negotiation (pp. 15-26). London: Routledge.

Clingempeel, W.G., \& Brand-Clingempeel, E. (2004). Pathogenic-conflict families and children: What we know, what we need to know. In Coleman M., \& Ganong L.H. (Eds.), Handbook of contemporary families: Considering the past, contemplating the future (pp. 244-261). Thousand Oaks, CA: Sage.

Cockett, M., \& Tripp, J. H. (1994). The Exeter family study: Family breakdown and its impact on children. Exeter: University of Exeter Press.

Corfman, K. P., \& Lehmann, D. R. (1987). Models of cooperative group decision-making and relative influence: An experimental investigation of family purchase decisions. Journal of Consumer Research, 14(1), 1-13.

Cusumano, M. A., Kahl, S. J., \& Suarez, F. F. (2015). Services, industry evolution, and the competitive strategies of product firms. Strategic Management Journal, 36(4), 559-575.

Dachs, B., Biege, S., Borowiecki, M., Lay, G., Jäger, A., \& Schartinger, D. (2012). The servitization of European manufacturing industries. Retrieved form https://mpra.ub.uni-muenchen.de/38873/1/MPRA_ paper_38873.pdf

Dinges, V., Urmetzer, F., Martinez, V., Zaki, M., \& Neely, A. (2015). The future of servitization: Technologies that will make a difference. Cambridge: Cambridge Service Alliance, University of Cambridge.

Drechsler, W. (2005). The re-emergence of "Weberian" public administration after the fall of new public management: The central and eastern European perspective. Administrative Culture, 6(1), 94-108.

Drechsler, W. (2009). The rise and demise of the New Public Management: Lessons and opportunities for South East Europe. Central European Public Administration Review, 7(3), 7-27.

Drechsler, W., \& Kattel, R. (2009). Conclusion: Towards the neo-Weberian state? Perhaps, but certainly adieu, NPM. The NISPAcee Journal of Public Administration and Policy, 1(2), 95-99.

Drechsler, W., \& Randma-Liiv, T. (2015). The new public management then and now: Lessons from the transition in Central and Eastern Europe. In de Vries M., \& Nemec J. (Eds.), Implementation of New Public Management Tools. Experiences from transition and emerging countries (pp. 33-49). Brussels: Bruylant.

Dunleavy, P., Margetts, H., Bastow, S., \& Tinkler, J. (2006). New public management is dead-long live digital-era governance. Journal of Public Administration Research and Theory, 16(3), 467-494.

Durose, C., Mangan, C., Needham, C., Rees, J., \& Hilton, M. (2013). Transforming local public services through co-production. Swindon: Arts and Humanities Research Council.

Eisingerné, B. B. (2014). Édesem vagy mostohák?: Vásárlási döntések a mozaikcsaládokban, Pécs, Magyarország, Győr. Magyarország: Széchenyi István Egyetem Regionális- és Gazdaságtudományi Doktori Iskola.

Eisingerné, B. B., \& Makkos-Káldi, J. (2012). "Biologic" in stepfamilies. 3rd Emac CEE Regional Conference, 6269. 
Fang, E., Palmatier, R. W., \& Steenkamp, J. B. E. (2008). Effect of service transition strategies on firm value. Journal of Marketing, 72(5), 1-14.

Felker, J. A., Fromme, D. K., Arnaut, G. L., \& Stoll, B. M. (2002). A qualitative analysis of stepfamilies: The stepparent. Journal of Divorce \& Remarriage, 38(12), 125-142.

Fergusson, D. M., Horwood, L. J., \& Shannon, F. T. (1984). A proportional hazards model of family breakdown. Journal of Marriage and the Family, 46(3), 539-549.

Filep, B., Földesi, P., \& Csík, Á. (2010). Competitiveness of cities, searching for a model to optimize cities. Acta Technica Jaurinensis, 3(3), 383-393.

Filep, B., \& Kovács, Zs. (2005). Karrierszolgáltatók a felsőoktatásban. Comitatus: Önkormányzati Szemle, 15(11-12), 82-86.

Fischer, E. (2005). Modern mostohák. Budapest: Saxum kiadó.

Fisher, P. A., Leve, L. D., O’Leary, C. C., \& Leve, C. (2003). Parental monitoring of children's behavior: Variation across stepmother, stepfather, and two-parent biological families. Family Relations, 52(1), 45-52.

Foxman, E. R., Tansuhaj, P. S., \& Ekstrom, K. M. (1989). Family members' perceptions of adolescents' influence in family decision making. Journal of Consumer Research, 15(4), 482-491.

Garrido, J. M. (2009). Object Oriented Simulation: A Modeling and Programming Perspective. Springer US.

Gerson, R., \& McGoldrick, M. (1993). Genogramas en la evaluación familiar. Barcelona: Gedisa.

Government Decree 149/1997 (IX.10.) on Guardianship Authorities and Child Protection and Guardianship Procedures Chapter IV. (Sections 27-33/B).

Hajnal, G. (2004). Administrative culture and New Public Management reforms: A multiple-case study. Budapest: University of Economics and Management.

Hajnal, G., Kádár, K., \& Kovács, É. (2018). Government Capacity and Capacity-Building in Hungary: A New Model in the Making?. NISPAcee Journal of Public Administration and Policy, 11(1), 11-39.

Hetherington, E. M. (1999). Family functioning and the adjustment of adolescent siblings in diverse types of families. Monographs of the Society for Research in Child Development, 64(4), 1-25. doi: 10.1111/15405834.00045.

Hockerts, K., \& Weaver, N. (2002, May). Towards a theory of sustainable product service systems - what are the dependent and independent variables of S-PSS. Proceedings of the INSEADCMER research workshop "Sustainable product service systems-key definitions and concepts.

Hood, C., \& Peters, G. (2004). The middle aging of new public management: into the age of paradox?. Journal of Public Administration Research and Theory, 14(3), 267-282.

Huszka, P., \& Platz, P. (2017). Középiskolások erkölcsi értékrendjének és a házassággal kapcsolatos attitűdjeinek vizsgálata I. In Dusek, T. (Ed.), A városi rendszer müködése: Közösségi szféra, oktatás és Győr jövőképe (pp. 104-134). Győr, Magyarország. Universitas-Győr Nonprofit Kft.
Jenei, G. (2009). A post-accession crisis? Political developments and public sector modernization in Hungary (No. 67). BERG Working Paper Series on Government and Growth.

Jeong, C. H. I. (2007). Fundamental of Development Administration. Selangor: Scholar Press

Jun, K. N., \& Weare, C. (2011). Institutional motivations in the adoption of innovations: The case of e-government. Journal of Public Administration Research and Theory, 21(3), 495-519.

Kaboolian, L. (1998). The new public management: Challenging the boundaries of the management vs. administration debate. Public Administration Review, 58(3), 189-193.

Kettl, D. F. (1995). Building lasting reform: Enduring questions, missing answers. In D. F. Kettle, \& Jr. J. DuIulio (Ed.), Inside the reinvention machine: Appraising governmental reform (pp. 9-83). Washington. D.C.: The Brookings Institution.

Kozłowska, J. (2020). What Influences the Servitization Process the Most? A Perspective of Polish Machinery Manufacturers. Sustainability, 12(12), 5056. doi: $10.3390 /$ su 12125056

Krähenbühl, V., Jellouschek, H., Kohaus-Jellouschek, M., \& Weber, R. (2011). Stieffamilien: Struktur-Entwicklung-Therapie. Lambertus-Verlag.

Kurdek, L. A., Fine, M. A., \& Sinclair, R. J. (1995). School adjustment in sixth graders: Parenting transitions, family climate, and peer norm effects. Child Development, 66(2), 430-445.

Kurucz, A. (2016). The SMEs surf in change flow. Tér-Gazdaság-Ember, 4, 109-121.

Lansford, J. E., Ceballo, R., Abbey, A., \& Stewart, A. J. (2001). Does family structure matter? A comparison of adoptive, two-parent biological, single-mother, stepfather, and stepmother households. Journal of Marriage and Family, 63(3), 840-851.

Lathrop, D., \& Ruma, L. (2010). Open government: Collaboration, transparency, and participation in practice. O’Reilly Media, Inc.

Lawton, J. M., \& Sanders, M. R. (1994). Designing effective behavioral family interventions for stepfamilies. Clinical Psychology Review, 14(5), 463-496.

Lindquist, E. A., \& Paquet, G. (1996). Government restructuring and the federal public service: The search for a new cosmology. Ottawa: Faculty of Administration, University of Ottawa.

Mes, M. (2017). Simulation Modelling using Practical Examples: A Plant Simulation Tutorial.

Meynhardt, T. (2009). Public value inside: What is public value creation?. International Journal of Public Administration, 32(3-4), 192-219.

Mintel, A. (2005). Marketing to Families. London: Mintel International Group Ltd.

Mintzberg, H. (1996). Managing government, governing management. Harvard Business Review, 74(3), 75-83.

Nabatchi, T., Sancino, A., \& Sicilia, M. (2017). Varieties of participation in public services: The who, when, and what of coproduction. Public Administration Review, 77(5), 766-776. 
Nambisan, S., \& Nambisan, P. (2013). Engaging citizens in co-creation in public services. IBM Center for Business Development.

Neely, A. (2007, June). The servitization of manufacturing: an analysis of global trends. 14th European Operations Management Association Conference (pp. 1-10). Turkey Ankara.

Neely, A. (2008). Exploring the financial consequences of the servitization of manufacturing. Operations $\mathrm{Ma}$ nagement Research, 1(2), 103-118.

Neely, A. (2013). Servitization in Germany: An international comparison. Cambridge Service Alliance, 1-10.

Neely, A., (2012). Society's Grand Challenges: What Role for Services? Cambridge Service Alliance Executive Briefing Paper. Cambridge, UK: University of Cambridge.

Neely, A., Benedettini, O., \& Visnjic, I. (2011). The servitization of manufacturing: Further evidence. 18th European Operations Management Association Conference.

Nemec, J. (2010). New Public Management and its Implementation in CEE: What do we Know and where do we Go? NISPAcee Journal of Public Administration and Policy, 3(1), 31-52.

Nemec, J., Svidroňová, M. M., \& Kovács, É. (2019). Welfare Co-Production: Hungarian and Slovak Reality. NISPAcee Journal of Public Administration and Policy, 12(2), 195-215.

Németh, K., \& Döry, T. (2019). Influencing factors of innovation performance in family firms-Based on an empirical research. Vezetéstudomány-Budapest Management Review, 50(5), 58-71.

O’Toole Jr, L. J., \& Meier, K. J. (2015). Public management, context, and performance: In quest of a more general theory. Journal of Public Administration Research and Theory, 25(1), 237-256.

Oliva, R., \& Kallenberg, R. (2003). Managing the transition from products to services. International Journal of Service Industry Management, 14(2), 1-10.

Osborne, D., \& Gaebler, T. (1992). Reinventing government: How the entrepreneurial spirit is transforming the public sector from schoolhouse to statehouse. City Hall to Pentagon. Reading, Mass., Addison-Wesley.

Osborne, S. P., \& Strokosch, K. (2013). It takes Two to Tango? Understanding the $\mathrm{C}$ o-production of Public Services by Integrating the Services Management and Public Administration Perspectives. British Journal of Management, 24, S31-S47.

Osborne, S. P., Radnor, Z., \& Nasi, G. (2013). A new theory for public service management? Toward a (public) service-dominant approach. The American Review of Public Administration, 43(2), 135-158.

Osborne, S. P., Radnor, Z., \& Strokosch, K. (2016). Co-production and the co-creation of value in public services: a suitable case for treatment?. Public Management Review, 18(5), 639-653.

Ostrom, E. (1972). Metropolitan reform: Propositions derived from two traditions. Social Science Quarterly, 53(3), 474-493.

O’Toole Jr, L. J. (1997). Treating networks seriously: Practical and research-based agendas in public administration. Public Administration Review, 45-52.
Papernow, P. L. (1993). Becoming a Stepfamily. San Francisco: Jossey-Bass Publishers.

Parks, R. B., Baker, P. C., Kiser, L., Oakerson, R., Ostrom, E., Ostrom, V., Percy S.L., Vandivort, M. B., Whitaker, G.P., \& Wilson, R. (1981). Consumers as coproducers of public services: Some economic and institutional considerations. Policy Studies Journal, 9(7), 10011011.

Pestoff, V. (2006). Citizens and co-production of welfare services: Childcare in eight European countries. Public Management Review, 8(4), 503-519.

Pollitt, C., \& Bouckaert, G. (2004). Public management reform: A comparative analysis. Oxford, USA: Oxford University Press.

Prateek Sh. (2015). Discrete-Event Simulation. International Journal of Scientific \& Technology Research, 4(04), 136-140.

Rámháp, S., Nagy, D., Országh, Á., Rechnitzer, J., \& Filep, B. (2017). Career Choice Motivation Of High School Students In Context Of Changing Higher Education In Knowledge Economy. Poslovna Izvrsnost: Znanstveni Časopis za Promicanje Kulture Kvalitete i Poslovne Izvrsnosti, 11(2), 23-37.

Reicher, R. (2014). CRM informatikai rendszer bevezetésének és müködtetésének vállalati problémái a magyar $K K V-k$ körében. Doctoral dissertation SZIE, Gödöllö.

Richwine, J. (2012). Government Employees Work Less than Private Sector Employees. Washington, DC: The Heritage Foundation.

Ringold, D., Holla, A., Koziol, M., \& Srinivasan, S. (2013). Citizens and Service Delivery: Assessing the Use of Social Accountability Approaches in Human Development. Washington, DC: World Bank.

Rodgers, K. B., \& Rose, H. A. (2002). Risk and resiliency factors among adolescents who experience marital transitions. Journal of Marriage and Family, 64(4), 1024-1037.

Sabbagh, K., Friedrich, R., El-Darwiche, B., Singh, M., Ganediwalla, S., \& Katz, R. (2012). Maximizing the Impact of Digitization. In The Global Information Technology Report (pp. 121-133). World Economic Forum.

Schumacher Dyke, K. (2005). Successful stepfamilies: A family life education program to address unique needs. Retrieved from https://etd.ohiolink.edu/!etd. send_file?accession=miami $1113921837 \&$ disposition=inline

Shikata, N., Goto, S., \& Gemba, K. (2019). Servitisation of manufacturing industry in Japan. Forum Scientiae Oeconomia, 7(3), 19-30. doi: 10.23762/FSO_VOL7_ NO3_2

Slack, N. (2005). Patterns of Servitization: Beyond Products and Service. An Initial Report on Initial Exploratory Work Undertaken January-April 2004. Institute for Manufacturing, CUEA.

Spéder, Zs. (2005). Az európai családformák változatossága. Párkapcsolatok, szülõi és gyermeki szerepek az európai országokban az ezredfordulón. Századvég, 3, 1-47.

Stark, A. (2002). What is the new public management? Journal of Public Administration Research and Theory: J-PART, 12(1), 137-151. 
Stoker, G. (2006). Public value management: a new narrative for networked governance?. The American Review of public administration, 36(1), 41-57.

Süle, E. (2018). A digitális technológiák és a termelékenységnövekedés. Logisztikai Évkönyv, 2019(25), 46-53.

Tamándl, L., Kovács, Zs., Rámháp, Sz., \& Nagy, D. (2014). A felsőoktatás térbeli szerkezete az Észak-Dunántúlon. In Dusek, T. (Eds.), A városi rendszer müködése (pp. 104-134). Universitas-Györ Nonprofit Kft.

Terry, L. D. (1999). From Greek Mythology to the real world of the new public management and democratic Governance (Terry Responds). Public Administration Review, 59(3), 272-277.

Tinson, J., \& Nancarrow, C. (2007). “GROw” ing up: tweenagers' involvement in family decision making. Journal of Consumer Marketing, 24(3), 160-170.

Tinson, J., Nancarrow, C., \& Brace, I. (2008). Purchase decision making and the increasing significance of family types. Journal of Consumer Marketing, 25(1), 45-56.

Vandermerwe, S., \& Rada, J. (1988). Servitization of business: adding value by adding services. European $\mathrm{Ma}$ nagement Journal, 6(4), 314-324.

Visher, E. B., \& Visher, S. (1995). Stiefeltern, Stiefkinder und ihre Familien. 2. neubearb. München: Psychologie Verlags Union.

Wise, R., \& Baumgartner, P. (1999). Go downstream. Harvard Business Review, 77(5), 133-141. 